\title{
Impact of organic techniques of seed crop management on seed yield and quality in rice
}

\section{R. Vijayan and V. Krishnasamy*}

Department of Seed Science and Technology, Tamilnadu Agricultural University, Coimbatore. 641003 (Tamil Nadu), INDIA

*Corresponding author. E-mail: vijayanr_78@yahoo.co.in

Received: May 14, 2014; Revised: October 14, 2014; Accepted: December 20, 2014

Abstract: A study was conducted at the Department of Seed Science and Technology, Tamilnadu Agricultural University, Coimbatore in June - July season of two different years to find out suitable organics for enhanced productivity of rice cv ADT 43 for organic seed production. The results revealed among the organic soil application of neem cake (1786 kg ha $\left.{ }^{-1}\right)$ along with 3 per cent panchakavya foliar spray maximized the yield along with yield attributing characters (plant height, total number of tillers hill ${ }^{-1}$, productive tillers hill ${ }^{-1}$, chlorophyll content, panicle length) and resultant organic seed quality characters. However, the yield was higher with basal nutrients applied as inorganic (3537 kg ha-1 in initial and $4352 \mathrm{~kg} \mathrm{ha}^{-1}$ in confirmation), which was on par with neem cake + panchakavya (3500 kg $\mathrm{ha}^{-1}$ in initial and $4315 \mathrm{~kg} \mathrm{ha}^{-1}$ in confirmation), GLM + azolla (3380 kg ha ${ }^{-1}$ in initial) and GLM + azolla + panchakavya (4213 $\mathrm{kg} \mathrm{ha}^{-1}$ in confirmation) treatments and sprayed with panchakavya at vegetative, flowering and maturity. These findings are highly useful for paddy organic seed production programme.

Keywords: Organic manures, Organic seed production, Quality seeds, Rice

\section{INTRODUCTION}

Rice (Oryza sativa L.) is the important world's staple food, particularly in South Eastern countries, while in India 70 per cent of the population depends on rice for their feeding. During the year 2010-11, rice with 94.01 million tonnes of production contributed to $40.5 \%$ of the total foodgrain production of the country (Anonymous, 2011). Venkataramani, (2002) also expressed that Asian people consume 92 per cent of the 90 per cent global rice production. India is the largest country with rice cultivated area of 44.97 million hectares and holds the second position in production (85.5 million tonnes) next to china and contributes 7.53 per cent of the world's total rice production.

In India, the green revolution undoubtedly helped to tide over the food crisis during the last four decades. Use of chemical fertilizers is one of the major factors for increasing the food production from 50 million tonnes to 200 million tonnes. Chemical fertilizers are the immediate source of nutrients in soils. Consumption of nitrogenous $(\mathrm{N})$, phosphatic $(\mathrm{P})$ potassic $(\mathrm{K})$ fertilizers has increased from 1.1 million tones in 1966 -67 , the year preceding the green revolution to 27.7 million tonnes in 2011-12 (Anonymous, 2013). Continuous usage of fertilizers enhanced the demand for fertilizers to the tune of about 28 million tonnes from the current level of 17 million tonnes and pesticides to 1.5 lakh tonnes as against current usage of 0.8 lakh tones that started expressing their ill effects with advances in periods. Inspite of increased use of costly inputs, it is not certain whether we could meet the challenge of feeding the people to desired extent with the right quality of safe food. At this juncture, a keen awareness has sprung on the adoption of organic farming as a remedy to cure the ills of modern chemical agriculture. Organic agriculture is environmental friendly ecological production system that promotes and enhances biodiversity, biological cycle and biological activities. It is based on minimal use of off-farm inputs and management practices that restore, maintain and enhance ecological harmony. The principal guidelines for organic production are to use materials and practices that enhance the ecological balance of natural systems and integrate the parts of the farming systems into an ecological holistic system. Organic agriculture practices cannot ensure that products are completely free from residues, however, methods are used to minimize pollution of air, water and soil reported by Mary, (2007). The primary goal of organic agriculture is to optimize the health and productivity of interdependent communities of tiring soil, plant, animals and people. Use of organic manures in one form or the other though inherent in Indian farming has advantages like nutrient conservation, slow release, improvement of soil physical conditions resulting in higher crop yields. For 
efficient nutrient management in a cropping system basis, the use of available organic resources such as Farmyard manure (FYM), compost, biogas slurry, green manure, green leaf manure, sewage sludge, urban waste, farm waste and crop residues should necessarily dovetailed for increasing soil productivity. Keeping in view of the nutrient needs of the crop, use of biofertilizers and microorganisms also could be adopted (Krishnappa et al., 1993). Since rice being cultivated throughout the year, quality seed production plays a vital part to supply seeds in time at reasonable cost. Seed production in rice varieties involves application of large quantities of inorganic inputs in the field as well as on the foliage of the crop to facilitate production of good quality seed. Hence, seed production using organic means is getting momentum now a days. As per the stipulations of International Federation of Organic Agriculture Movements (IFOAM), sowing organic seed has become mandatory for organic agriculture since 2003. Nutrition to mother crop plays a significant role in improving the yield and quality of seed. Maximum yield is a constantly moving target because of continuing technological advance. Organic nutrient management has more often been used as low and locally available input sustainable agriculture by maintaining soil fertility (Mader et al.,2002). The present study was therefore initiated to study the effect of mother crop nutrition in relation to organics and to compare with the inorganic inputs on seed yield and quality in rice cv. ADT 43 in the June July season of 2003 as initial and 2004 as confirmation trail

\section{MATERIALS AND METHODS}

The experiment was designed in Randomized Block Design with three replications during June - July season for consequent two years (initial and confirmation). The area were ploughed and puddled well adopting RBD with three replication, the plots of size $3.25 \times 3.25 \mathrm{~m}$ (net plot size $3 \times 3 \mathrm{~m}$ ) were segregated and the the basal application of nutrients in different form of organic viz., $\left(\mathrm{T}_{1}\right)$ Neem cake (1786 $\left.\mathrm{kg} \mathrm{ha}{ }^{-1}\right),\left(\mathrm{T}_{2}\right)$ Biogas slurry $\left(5555 \mathrm{~kg} \mathrm{ha}^{-1}\right), \mathrm{T}_{3}$ Vermicompost (3333 $\mathrm{kg} \mathrm{ha}^{-1}$ ), $\mathrm{T}_{4}$-GLM (Green Leaf Manure) (3641 kg ha-1) + Azolla (1000 kg ha $\left.{ }^{-1}\right), \mathrm{T}_{5}-$ FYM (Farm Yard Manure ) (12500 kg ha-1) were applied based on the inorganic nitrogen recommended for the crop. Each of the above set of treatment were also sprayed with three per cent panchakavya $\left(\mathrm{T}_{6}-\mathrm{T}_{1}\right.$ + Panchakavya, $\mathrm{T}_{7}-\mathrm{T}_{2}+$ Panchakavya, $\mathrm{T}_{8}-\mathrm{T}_{3}+$ Panchakavya, $\mathrm{T}_{9}-\mathrm{T}_{4}+$ Panchakavya, $\mathrm{T}_{10}-\mathrm{T}_{5}+$ Panchakavya, ) at vegetative, flowering and seed maturation stages. These organic treatments were also compared with $\left(\mathrm{T}_{11}\right)$ inorganic nutrient source @ 100 : $50: 50 \mathrm{~N} \mathrm{P} \mathrm{K} \mathrm{kg} \mathrm{ha}^{-1}$ as per the recommendation of CPG, (1999). Twenty five day old seedlings organically produced seedlings (applied with FYM only) were transplanted after root dipping in 2 per cent
Pseudomonas and transplanted at the spacing of $15 \mathrm{x}$ $10 \mathrm{~cm}$. During the growth period, based on need the plant protection measures were taken with organic products such as Neem based products (3 $\mathrm{ml} /$ lit) (Neem oil)and Pseudomonas for plots evaluated for organic farming, while for $\mathrm{T} 11$, the inorganic nutrient source monocrotophos ( $2 \mathrm{ml} / \mathrm{lit})$ was sprayed. The panchakavya stock solution was prepared using $5 \mathrm{~kg}$ of Cowdung, 3 litres of cow's urine, 2 litres, of cow's milk, 2 litres of cow's curd and 1 litre of cow's clarified butter / ghee as per Natarajan (1999) and were diluted to three per cent for the spray. During crop growth, observations on plant and yield attributes like plant height, days to 50 per cent flowering, leaf folder incidence, number of tillers, number of productive tillers, panicle length, chlorophyll (Yoshida et al., 1972), total number of spikelets panicle ${ }^{-1}$, number of filled seeds panicle ${ }^{-1}$, number of ill-filled seeds panicle ${ }^{-1}$, seed yield plant ${ }^{-1}$, seed yield plot $^{-1}$, computed seed yield $\mathrm{ha}^{-1}$. The resultant seeds were also evaluated for seed quality attributes like seed recovery, seed to husk ratio, seed hardness (Viswanathan et al., 1997), 100 seed weight (ISTA, 1999), seed germination (ISTA, 1999), drymatter production (ISTA, 1999) and vigour index (AbdulBaki and Anderson, 1973). The seeds were also evaluated for field emergence (\%) after thiry days of sowing and the seedlings were measured for the vigour parameters such as drymatter production (ISTA, 1999), vigour index (Abdul-Baki and Anderson, 1973). In addition the seed biochemical attributes like total sugars (Hodge and Hofreiter, 1962), protein content (Piper, 1966), ATPase (Unbreit et al., 1964), alpha amylase (Simpson and Naylor, 1962) and dehydrogenase activity (Kittock and Law, 1968). The data gathered were evaluated for their significant difference at 5 per cent probability as per Panse and Sukhatme, (1999).

\section{RESULTS AND DISCUSSION}

Plant height referred as an index of plant growth, was maximum in neem cake + panchakavya during initial trial, while during confirmation trial, inorganic treatment was the best ,but was followed by neem cake + panchakavya (Table 1). Natarajan (2002) has also reported that organic manure application enhanced the rice plant growth attributes. Foliar application of panchakavya enhanced the absorption of nutrients, thus increasing the plant height (Sebastian, 2005 and Srimathi et al.,2013). Early flowering was noticed in plots applied with neem cake + panchakavya which were on par with the recommended practice of inorganic treatment (Table 1) in both the trials. Early flowering might also be due to early accomplishment of initial stages and correspondingly all other stages of growth, owing to the cumulative effect of both soil and foliar nutrition and also presence of GA and other growth promoting substances in panchakavya (Saritha et al., 2013). Similar advancement of flowering by organic 
R. Vijayan and V. Krishnasamy/ J. Appl. \& Nat. Sci. 6 (2): 857 - 868 (2014)

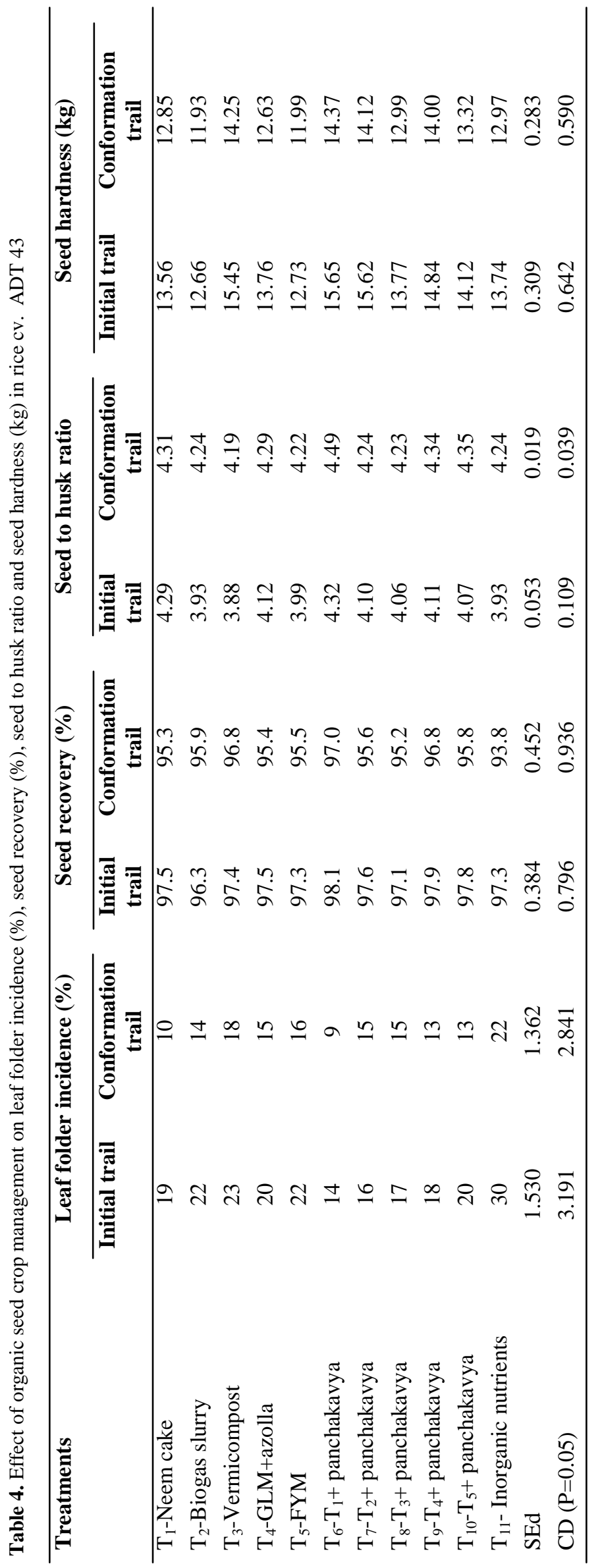


R. Vijayan and V. Krishnasamy/ J. Appl. \& Nat. Sci. 6 (2): 857 - 868 (2014)

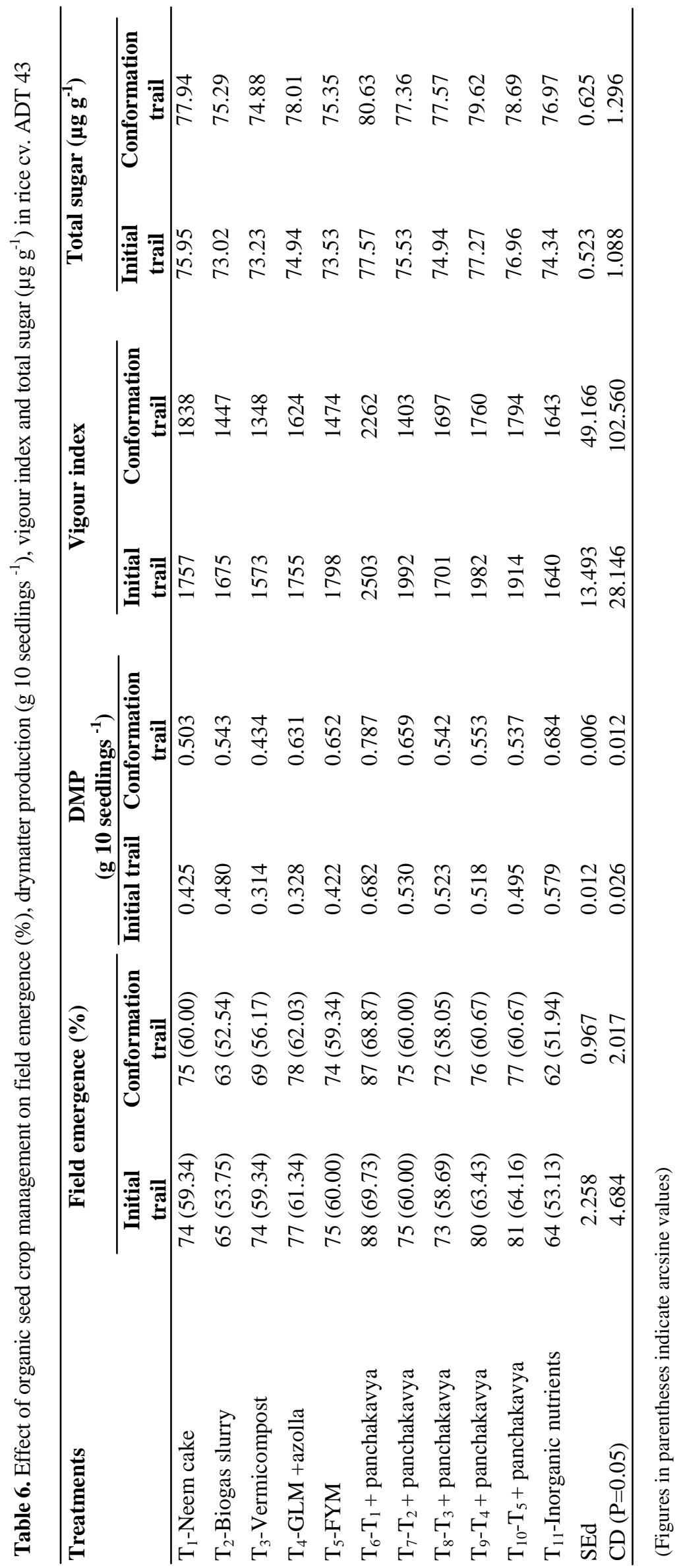




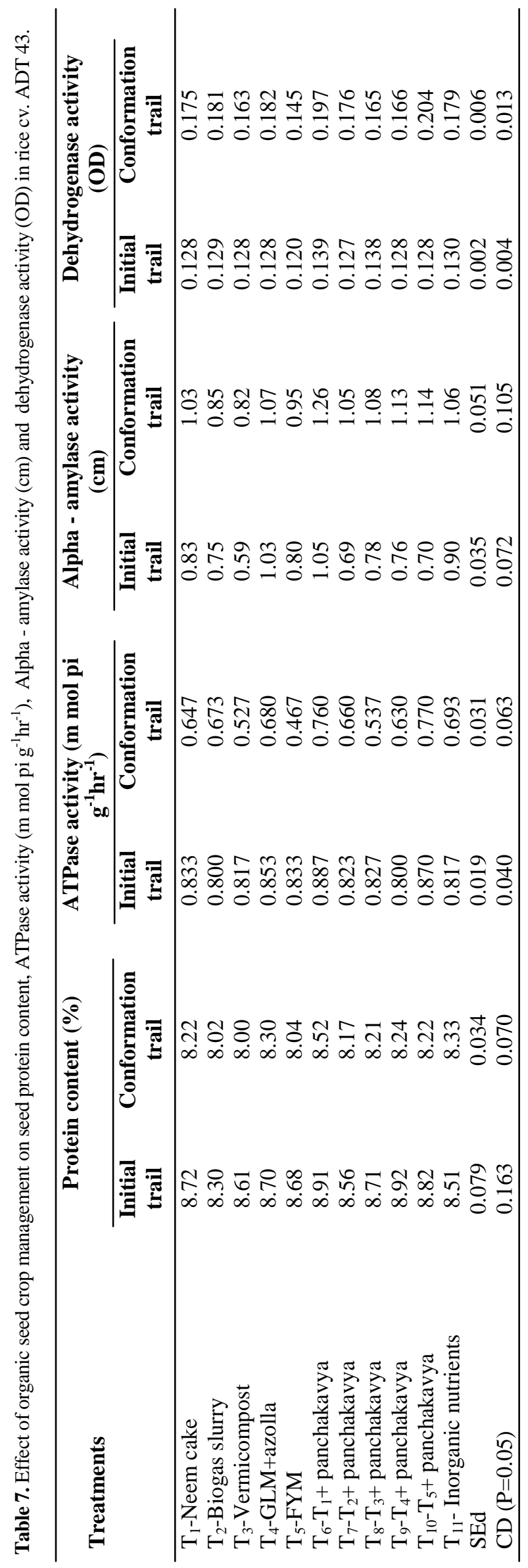


manure + panchakavya in green gram, maize and sunflower were reported by Somasundram (2003) and Shakuntala et al. (2012) in rice.

Total number of tillers varied significantly in all stages (vegetative, flowering and maturity) on account of treatments. Inorganic plots registered the maximum number of tillers and productive tillers which was on par with neem cake + panchakavya (Table 1). Increase in plant height and number of tillers was mainly due to $\mathrm{N}$ as reported by De Datta (1981) in rice and in addition to involvement of certain growth substances like IAA (Sen and Bose, 1959) in rice. Application of organic in combination with inorganic fertilizers or biofertilizers or micronutrient have recorded the more number of productive tillers in rice as reported by Hattb (1995). Inorganic treatment and neem cake + panchakavya were again on par in registering maximum panicle length (Table 2). Panicle length even though controlled partly by genetic character that was influenced by nutrition as reported by Matsushima, 1980).

The other yield components like, total number of spikelets panicle ${ }^{-1}$, filled seeds panicle $^{-1}$ were the highest in neem cake + panchakavya (Table 2) because of balanced supply of nutrients through out the growth period and proper physiological partitioning from source to sink. By virtue of the ability to provide the nutrients in a steady manner, organics would have increased the filled seeds as compared to inorganic treatment. The maximum chlorophyll content was recorded in inorganic treatment (Table 3).

Chlorophyll is important nitrogen containing compound of the green plants (Mishra and Srivastava, 1983). Neem cake + panchakavya also showed beneficial effect in chlorophyll, which was on par with inorganic fertilizers. The seed yield plant $^{-1}$, seed yield plot $^{-1}$ and computed seed yield were maximum in inorganic plot $\left(3537 \mathrm{~kg} \mathrm{ha}^{-1}\right.$ in initial trail and $4352 \mathrm{~kg}$ $\mathrm{ha}^{-1}$ in confirmation trail), which was on par with neem cake + panchakavya $\left(3500 \mathrm{~kg} \mathrm{ha}^{-1}\right.$ in initial trail and $4315 \mathrm{~kg} \mathrm{ha}^{-1}$ in confirmation trail),GLM + azolla (3380 $\mathrm{kg} \mathrm{ha}{ }^{-1}$ in initial trail) and GLM + azolla + panchakavya (4213 $\mathrm{kg} \mathrm{ha}^{-1}$ in confirmation trail) treatments (Table 3). The yield level attained in inorganic might be due to the immediate availability of nutrients to the plants. Quantity of organics was calculated on equal nitrogen basis. However, inorganic plot received $\mathrm{P}$ and $\mathrm{K}$ at a dose of $50 \mathrm{~kg}$ each per hectare respectively. Organics might not be in a position to make available this much quantity of $\mathrm{P}$ and $\mathrm{K}$ to the plants. However, some of the organically treated plots also performed on par with inorganic treatment due to other bioactive compounds available in organics.Aapplication of neem cake + panchakavya, GLM + azolla and GLM + azolla + panchakavya evoked response to a greater level as that of inorganic fertilizer application.

Organic matter increased the availability of unavailable plant nutrients by enhancing the biochemical activity of soil microorganisms. Koyama (1975) opined that even under heavy nitrogen application about 68 per cent of $\mathrm{N}$ absorbed by rice was from soil $\mathrm{N}$ and humus is an important source of $\mathrm{N}$ in soil. The organic source of the treatment might have improved the availability of micronutrients well by binding and protecting them from losses. The bound nutrients will be released for assimilation by plants. Beneficial effects of panchakavya on yield have been reported by Sridhar et al. (2001) in rice, Somasundaram (2003) in maize, green gram and sunflower, Kumaravelu and Kadamban (2009) in greengram and Padmapriya et al.(2010) in Gymnema sylvestre. It is also supported by the presence of low leaf folder incidence in neem cake + panchakavya applied plot and it was higher in inorganic nutrients $(30 \%$ in initial trail and $22 \%$ in confirmation trail) (Table 4).

Seed quality attributes viz., seed to husk ratio, seed hardness and 100 seed weight of size graded seeds (1.5 $\mathrm{mm}$ x $19 \mathrm{~mm}$ slotted hole sieve) were significantly influenced by organic manures. Percentage recovery of seeds upon grading with $1.5 \mathrm{~mm}$ x $19 \mathrm{~mm}$ slotted hole sieve were higher in most of the organic treatments (Table 4). Higher seed hardness, seed to husk ratio and 100 seed weight were maximum in neem cake + panchakavya (Table 4 and 5). In general, seeds harvested from organic plots recorded higher hardness than inorganic plot (Table 4). This might probably be due to availability of additional growth promoting substances in the organics in addition to major nutrients. Another reason could be that the ready availability would have enabled the plant to absorb more nitrogen resulting in increased succulence of cell wall causing reduced hardness in the seeds of inorganic plots. Chandrgiram et al. (1987) reported that the highest seed hardness in wheat was recorded in control treatment (unfertilized plot). Similar effect of organic on 1000 seed weight was reported by Kenchaiah (1997) in rice.

In any seed production activity, achieving high level of germination is the prime objective. As per minimum seed certification standards rice seeds should posses at least 80 per cent germination. In this study not only organically produced seed but also seed produced from inorganic treatment registered a germination level of above 80 per cent. However, inorganic seeds had 5 and 8 per cent lesser germination during initial and confirmation trail, respectively than the best organic combination of neem cake + panchakavya (Table 5). Better germination of seeds of the neem cake + panchakavya treatment might be because of increased fillness as revealed from seed to husk ratio and 100 seed weight. Biochemical estimations involving protein content, ATPase activity, alpha-amylase, total sugars and dehydrogenase showed the superiority of neem cake + panchakavya treatment, which again would have been the reason for higher germination ( Krishnasamy and Seshu, 1990). 
Seed quality, apart from genetic and physical purity, includes viability, health, structural soundness, size and vigour, all of which may influence the performance of a seed. Seedling vigour measured through dry matter production and vigour index was maximum in neem cake + panchakavya (Table 5). This again would have been the result and effect of higher seed weight, protein content and enzyme activity present in this treatment. Field emergence is the ultimate measure of seed vigour (Tonkin, 1969).The superior quality seeds produced in neem cake + panchakavya conformed with higher field emergence per cent, dry matter and vigour index in the field emergence test (Table 6). The reason for the favourable effect of neem cake + panchakavya might be due to higher 100 seed weight and better biochemical attributes.

The biochemical attributes like total sugar, protein, ATPase and alpha-amylase activity were higher in neem cake + panchakavya (Table 6 and 7). Kenchaiah (1997) reported improvement of protein due to neem cake application in rice. Increase in protein content due to panchakavya spray was reported by Somasundaram (2003) in maize, green gram and sunflower and Sebastian (2005) in sunflower. Dutta (1979) had amply demonstrated in rice, the positive association of viability and vigour with dehydrogenase activity. The dehydrogenase activity significantly differed among treatments where in neem cake + panchakavya registered maximum activity.

\section{Conclusion}

It was concluded that there was no much significant difference between inorganic and neem cake + panchakavya 3 percent spray treatment. But seed quality parameters viz., seed germination, seed filling and field emergence was significantly maximum in organic treatment than inorganic treatment. In addition to above, the neem cake + panchakavya treatment would not cause any problem to the soil, water and to the rice consumer. Because of this property and for sustaining the paddy seed production neem cake and panchakavya treatment was the best when compared to rest of the treatments. Hence, the finding would be highly useful for organic paddy seed production.

\section{REFERENCES}

Abdul-Baki, A.A. and Anderson. (1973). Are changes in cellular organelles for membranes related to vigour loss in seed. Seed Sci. \& Technol., 1: 89-125.

Anonymous. (2011). National Conference on Agriculture for Kharif Compaign-2011, Department of Agriculture \& Cooperation, Ministry of Agriculture, Government of India. New Delhi, India. pp 1; 57-67.

Anonymous. (2013). State of Indian Agriculture 2012-2013, Government of India, Ministry of Agriculture, Department of Agriculture and Cooperation, Directorate of Economics and Statistics, New Delhi, pp 14-15.

Chandgiram, R.K., Choudhury. and Singh, I. (1987). Farm universities - status of wheat seed production. Seeds and Farms, 13(1): 39-40.

De Datta, S.K. (1981). Principles and practices of rice production. John Wiley and Sons, New York, p. 618.

Dutta, G.C. (1979). Seed quality studies in some important cultivars of rice. M.Sc.(Ag.) Thesis, Tamil Nadu Agricultural University, Coimbatore.

Hattb, O.K. (1995). Studies on the combined effect of organic and inorganic nitrogen sources of nutrient release, yield and quality of rice. Ph.D., Thesis, Tamil Nadu Agricultural University, Coimbatore.

Hodge, J.E. and Hofreiter, B.T. (1962). Determination of reducing sugars and carbohydrates. I. Analysis and preparation of sugars. Methods in carbohydrate chemistry. Ed. By. R.L. Whistler and J.N. Beniller. Academis Press, New York. London.

ISTA. (1999). International Rules for Seed Testing. Seed Sci. \& Technol., Supplement Rules. 27: 25-30.

Kenchaiah, K. (1997). Organic farming studies in rice. Ph.D. Thesis, Tamil Nadu Agricultural University, Coimbatore.

Kittock, P,A. and Law, A.G. (1968). Relationship of seedling vigour to respiration and tetrazolium chloride reduction of germinating wheat seeds. Agron. J., 60: 286-288.

Koyama, T. (1975). Practice of determining potential nitrogen supplying capacities of paddy soils and rice yield. J. Sci. Soil Manure, 46: 260-269.

Krishnappa, A.M., Gajanana, C.N. and Ananthanarayana, R. (1993). Accent on integrated nutrient management for sustainable soil fertility Dr. S.V. Govinda Rajan memorial seminar on land, people and environment. 19, (March), pp. 19-24.

Krishnasamy, V. and Seshu, D.V. (1990). Alpha amylase activity in relation to seed vigour in rice. Proc. Int. Conf. Seed Sci. \& Technol., New Delhi. p. 88.

Kumaravelu, G. and Kadamban, D. (2009). Panchagavya and its effect on the growth of the greengram cultivar K851. Int. J. Plant Sci., 4(2):409-414.

Mader, P., Fliessbach, A., Dubois, D., Gunst, L., Fried, P. and Niggli, U. (2002). Soil Fertility and Biodiversity in Organic Farming. Science 296 : 1694-1697.

Mary V. G. (2007). Organic production/ organic food: Information assess tools, June 2007 from www.nal.usda.gov/afsic/pubs/ofp/ofp.shtml

Matsushima, S. (1980). Rice cultivation for Million. Japan Scientific Societies Press, Tokyo, pp. 260-275.

Mishra, S.N. and Srivastava, H.S. (1983). Role of inorganic nitrogen in the synthesis and degradation of chlorophyll and carotenoids in maize leaves. Biologia plantarum, 25 (1): 21-27.

Natarajan, K. (2002). Panchakavya - A manual. Other India Press, Mapusa, Goa, India, p. 33.

Padmapriya, S., Kumanan, K. and Rajamani, K. (2010). Studies on effect of organic amendments and bio-stimulants on morphology, yield and quality of Gymnema sylvestre. African Journal of Agricultural Research, 5(13), pp. 1655-1661.

Panse, V.G. and Sukhatme, P.V. (1999). In: Statistical methods for agricultural workers. ICAR, Publication, New Delhi, pp. 327-340.

Piper, C.S. (1966). Soil and plant analysis. International Science Publishers. Inc., New York.

Saritha,M., Vijayakumari, B., Yadav, H.R. and Kandari, L.S. (2013). Influence of Selected Organic Manures on the Seed Germination and Seedling Growth of Cluster Bean (Cyamopsis tetragonoloba (L.) Taub). Sci. Technol. Arts Res. J., 2(2):16-21. 
Sebastian, P.S. (2005). Impact of organic farming practice on soil health yield and quality of sunflower (Helianthus annus L.). M.Sc. (Ens) Thesis, Tamil Nadu Agricultural University, Coimbatore.

Sen, P.K. and Bose, T.C. (1959). Effect of growth regulating substances on rice. Indian Agrist., 36(1): 13-16.

Shakuntala, N.M., Vasudevanm, S.N., Patil, S.B., Doddagoudar, S.R., Macha, R.C.M.S.I. and Vijaykumar, A.G. (2012). Organic biopriming on seed vigour inducing enzyme in paddy - An alternative to inorganics. Ecoscan, 1:251-257.

Simpson. and Naylor. (1962). Dormancy studies in seeds of Avena fatua - 3. A relationship between maltose, amylose and gibberellin. Can J. Bot., 40: 1599-1673.

Somasundaram, E. (2003). Evaluation of organic sources of nutrient and Panchagavya spray on the growth and productivity of maize-sunflower-green gram system. Ph.D. Thesis, Tamil Nadu Agricultural University, Coimbatore.

Sridhar, S., Arumugasamy, S., Vijayalakshmi, K. and
Balasubramanian, A.V. (2001). Vikshayurveda : Ayureveda for plant - A user manual, Clarion 1: 6.

Srimathi, P., Mariappan, N., Sundaramoorthy, L. and Paramathma, M. (2013). Efficacy of Panchagavya on seed invigoration of biofuel crops. Scientific Research and Essays, 8(41) : 2031-2037.

Tonkin, J.H.B. (1969). Seedling evaluation. The use of soil tests. Proc. Intl. Seed Test. Ass., 34: 281-289.

Unbreit, W.W., Burris. R.H. and Stanferr, J.F. (1964), Cherry fruit development : The use of micro assay for studying IAA oxidase, Manometeric techniques. Pl. Growth Reg. , 2: 57-64.

Venkataramani, G. (2002). Policies need to be farmer friendly. Survey of Indian Agriculture, pp.5.

Viswanathan, R., Pandiyarajan, T. and Varadaraju, N. (1997). Physical and mechanical properties of tomato fruits related to pulping. J. Food Sci. Technol., 34(6):

Yoshida, S., Forno, D.A., Cock, J.H. and Gomez, K.A. (1972). Laboratory manual for physiological studies of rice. Int. Rice Res. Newsl., (Phillipines). pp. 70. 